\title{
KONTEKS EKSTERNAL VIRTUAL DALAM PRAGMATIK SIBER
}

\section{VIRTUAL EXTERNAL CONTEXTS IN CYBERPRAGMATICS}

\author{
R. Kunjana Rahardi \\ Universitas Sanata Dharma \\ Jalan Affandi, Catur Tunggal, Depok, Sleman, Yogyakarta 55281 \\ Pos-el: kunjana.rahardi@gmail.com
}

*) Naskah diterima: 12 April 2020; direvisi: 3 September 2020; disetujui: 6 Oktober 2020

\begin{abstract}
Abstrak
Penelitian ini bertujuan menggambarkan satu aspek penting dalam pragmatik siber, yakni kontekseksternal virtual. Rumusan masalah penelitian ini adalah bagaimana wujud pergeseran konteks menuju konteks eksternal virtual dalam pragmatik siber. Data penelitian ini adalah elemen elemen-konteks yang membentuk konteks virtual dan hadir bersama tuturannya. Data dikumpulkan dan disajikan dengan metode simak. Data yang terkumpul diklasifikasi dan ditipikasi sehingga ditemukan manifestasi data yang benar-benar siap dianalisis. Metode analisis yang diterapkan adalah metode padan, khususnya padan ekstralingual. Hasil penelitian menunjukkan bahwa terdapat manifestasi pergeseran pada lima elemen konteks. Kelima wujud pergeseran tersebut adalah: (1) elemen penutur, mitra tutur, dan pelibat tutur; (2) elemen setting suasana, waktu, dan tempat; (3) elemen maksud dan tujuan; (4) elemen saluran dan peranti tuturan; (5) elemen genre dan laras tuturan.
\end{abstract}

Kata kunci: konteks eksternal konvensional, konteks eksternal virtual, pragmatik siber

\begin{abstract}
This study aims to describe one important aspects of cyberpragmatics, namely the virtual external context. The research problem is formulated as follows: how the context shift to virtual external contexts in cyber pragmatics. The data of this research were elements of contexts that form the virtual context and are present with the speech. Data were collected and presented using the observation method. The collected data were classified and typified that thry were really ready to be analyzed. The analytical method applied was the equivalent method, especially the extralingual equivalent. The results showed that there were manifestations of shifts in the five elements of contexts. The five forms of the shifts are: (1) elements of speakers, speech partners, and speech actors; (2) setting elements of atmosphere, time and place; (3) elements of purpose and objective; (4) channel elements and speech tools; (5) genre and tone elements.
\end{abstract}

Keywords: conventional external contex,; virtual external context, cyberpragmatics

\section{PENDAHULUAN}

Pragmatik sebagai perspektif ataupun bidang ilmu hadir setelah tata bahasa berkembang dalam linguistik formal (Rahardi, 2017); (Haider, 2019). Formalisme dalam linguistik ditandai oleh pandangan strukturalistik, yakni pandangan yang lebih berfokus melihat bentuk (form) dan makna (meaning) (Giordano, 2016). Oleh karena itu, linguistik dipandang berhierarki dari tataran paling dasar menuju tataran yang paling kompleks (Allan \& Jaszczolt, 2012). 
Sebagai bidang terbaru dalam ilmu bahasa, pragmatik mengkaji maksud penutur dengan tidak melepaskan konteks. Maksud itulah yang disebut makna pragmatik. Jadi, makna pragmatik sangat dipengaruhi oleh asumsi-asumsi personal dan komunal dari para pelibat tuturnya. Asumsiasumsi tersebut terwadahi dalam konteks, baik yang sifatnya sosial, sosietal, kultural, maupun situasional (Rahardi, 2020); (Gretsch, 2009). Dengan perkataan lain, pragmatik merupakan studi bahasa yang terikat konteks (context-bound). Konteks yang berlaku pada pragmatik bersifat triadik, bukan bersifat diadik sebagaimana yang terdapat dalam semantik (Wijana, 2014); (Leech, 2007). Penelitian ini akan berfokus pada konteks dalam pragmatik siber yang jati diri elemen-elemennya merupakan pergeseran dari elemen-elemen konteks dalam pragmatik umum. Konteks dalam pragmatik umum disebut konteks eksternal konvensional, sedangkan konteks dalam pragmatik siber disebut dengan konteks eksternal virtual (Rahardi, 2015). Tulisan ini berfokus pada jenis konteks yang disebut terakhir itu.

\section{LANDASAN TEORI}

Perkembangan pragmatik yang paling baru bertautan erat dengan perkembangan teknologi dan dunia siber yang melahirkan pragmatik baru yang disebut pragmatik siber (cyberpragmatics). Tentang hal ini, Yus (2011) dan Locher (2011) telah membuat kajian yang cukup menantang dan mendalam. Bidang baru dalam pragmatik ini mengkaji maksud penutur dengan cara mendasarkan intepretasinya pada konteks, baik sosial, sosietal, kultural, maupun situasional yang bersifat virtual. Oleh karena itu, kajian konteks dalam pragmatik siber tidak lepas dari media sosial (Yus, 2012); (Locher, 2013a). Data ihwal konteks virtual tersebar luas dalam berbagai macam jenis media sosial yang mudah sekali diakses semua orang.

Tuturan-tuturan di media sosial, baik yang berupa tuturan kebencian, tuturan bernuansa kelakar, tuturan bernuansa kebohongan, maupun semacamnya dapat menjadi objek sasaran penelitian, data, dan sumber data substantif yang melimpah. Istilah cyberpragmatics ini banyak disebut pula oleh Miriam A. Locher (2013) sebagai internet pragmatics atau internet-mediated pragmatics.

Dunia digital atau yang lazim disebut dunia internet telah mengubah komunitas tutur yang lazim digunakan dalam disiplin sosiolinguistik, menjadi komunitas virtual. Dalam komunitas virtual, pengertian kesamaan verbal repertoire seolah-olah tidak berlaku lagi (Orsini-Jones et al., 2019); (Locher, 2013a). Siapa pun yang bergabung dalam komunitas virtual itu tidak memiliki batas-batas identitas yang pasti. Jadi, sangat berbeda dengan komunitas tutur atau komunitas sosial. Konteks yang berlaku dalam komunitas virtual juga berubah dramatis sehingga pragmatik siber mensyaratkan seseorang memahami konteks bukan lagi secara konvensional, tetapi secara virtual (Rahardi, 2018a).

Selanjutnya, perlu disampaikan bahwa Mey (1998) telah menemukan pemahaman baru terkait dengan konteks sosial. Mey (1998) menekankan pada dimensi vertikal hubungan masyarakat. Dengan perkataan lain, orientasi Mey (1998) lebih ke dimensi status dan jenjang sosial, bukan ke dimensi jarak sosial yang bersifat horizontal. Dimensi kekuasaan atau kekuatan (power) lebih dikedepankan Mey (1998) daripada dimensi solidaritas (solidarity). Jadi berbeda dengan perspektif Hymes (1972) yang melihat konteks pada dimensi horizontal kemasyarakatan (Ishihara, 2010).

Berbeda dengan yang dipaparkan di depan, konteks berdimensi kultural telah 
disampaikan oleh Halliday (1996). Hal ini disampaikan untuk memahami maksud penutur dalam kaitan dengan dimensi kultural, interkultural, dan mungkin juga antarkultural. Pandangan Halliday (1996) di atas sangat gayut dengan pandangan Blumkulka (2011), yang juga menekankan perspektif lintas budaya (Yu, 2011).

Berkaitan dengan teori konteks, Malinowski (1923) banyak dicatat sebagai sosok yang menginisiasi konteks situasi. Istilah tersebut ditelurkan ketika dia menerjemahkan teks-teks etnografinya pada masyarakat Trobrian Kepulauan Pasifik (Malinowski, 1925). Dalam perspektifnya, pelepasan konteks ternyata membuahkan hasil kerja etnografi yang tidak benar.

Hal-hal mendasar berkaitan dengan perkembangan ilmu pragmatik dan studi konteks yang disampaikan di depan itu semuanya diperantikan sebagai kerangka referensi dalam penelitian ini.

Penelitian ini dapat dianggap sebagai salah satu wujud studi awal tentang konteks virtual untuk menanggapi keprihatinan dan kelangkaan studi konteks dalam perspektif pragmatik siber yang masih langka.

\section{METODE PENELITIAN}

Metodologi dalam penelitian ilmu bahasa sangat krusial karena hal tersebut bertali-temali dengan objek penelitian, alat penelitian, dan cara menggunakan alat penelitian itu sendiri.

Objek penelitian bertautan dengan apa yang sesungguhnya hendak diteliti. Peneliti harus memastikan terlebih dahulu apa sesungguhnya objek telitian yang mau diangkat, termasuk memformulasikan kejatian datanya dan sumber datanya (Sudaryanto, 2016). Objek penelitian ini adalah konteks eksternal virtual, baik yang menyangkut hakikatnya maupun pergeserannya dalam pragmatik siber. Selanjutnya, data sesungguhnya adalah bahan jadi penelitian itu sendiri. Sebagai bahan jadi penelitian, data harus terlebih dahulu diidentifikasi, diklasifikasi, dan ditipifikasi secara cermat. Hanya data yang telah terklasifikasi dan tertipifikasi secara cermatlah yang dapat dikenai metode dan teknik penelitian. Data penelitian ini adalah konteks eksternal virtual yang hadir bersama dengan wujud tuturannya (Mahsun, 2005). Tidak mungkin konteks hadir sendiri tanpa ada tuturan naturalnya. Adapun sumber datanya adalah media sosial dalam berbagai jenis sebagai sumber data lokasional dan cuplikancuplikan tuturan beserta konteksnya sebagai sumber data substantifnya.

Data dikumpulkan dan disajikan dengan menggunakan metode simak. Metode simak diterapkan dengan melaksakanan penyimakan terhadap data dan sumber datanya sehingga diperoleh data yang benar-benar siap untuk dianalisis. Sebelum data dianalisis, data tersebut ditriangulasi untuk memperoleh validitas data (Sembiring, Pranowo, \& Rahardi, 2019). Triangulasi dilaksanakan dengan menggunakan triangulasi teori, yakni dengan mengonfirmasikan data yang telah ditemukan tersebut dengan teori yang ada. Selain itu, data juga ditriangulasi oleh pakar, yakni pakar sejawat yang memang memiliki kompetensi dan kepakaran di bidang pragmatik dan konteks pragmatik (Rahardi, 2019a).

Data yang telah terkumpul tersebut kemudian diklasifikasi dan ditipifikasi sehingga ditemukan manifestasi data yang benar-benar siap untuk dikenakan metode dan teknik analisis. Metode analisis yang diterapkan adalah metode padan, khususnya padan yang bersifat ekstralingual. Selanjutnnya, hasil analisis disajikan dengan metode sajian informal. 


\section{HASIL DAN PEMBAHASAN}

\section{Hasil Penelitian}

Data yang telah terkumpul dan tersaji dengan baik dalam penelitian tentang pergeseran manifestasi konteks pragmatik untuk penyusunan artikel ini secara keseluruhan berjumlah 10 buah. Manifestasi data lengkap dengan konteks yang menyertainya disajikan dengan kodifikasi datanya dalam tabel 1 berikut. Dari data tersebut kelihatan bahwa elemen data dalam pragmatik siber tidak sama dengan elemen data pada pragmatik sistemik, pragmatik umum, ataupun pragmatik berbasis kultur spesifik.

Dalam pragmatik siber, terdapat elemen data lain yang tidak ditemukan pada jenisjenis pragmatik lainnya. Hal demikian disebabkan oleh kenyataan bahwa dalam perspektif pragmatik siber, konteks itu tidak dapat dilepaskan dengan masyarakat virtual. Berbeda dengan jenis-jenis pragmatik lainnya yang lebih mendasarkan pada komunitas tutur tertentu, pragmatik siber lebih mengakomodasi komunitas virtual.

Perjumpaan yang lazimnya berciri semuka dalam komunitas tutur biasa, dalam komunitas siber tersebut perjumpaan tidak harus bersifat semuka. Kalau pun dijadikan semuka, kesemukaan itu bersifat 'diadakan' alias direpresentasikan dalam wujud gambar digital atau mungkin berwujud video. Gambaran data selengkapnya terlihat pada tabel berikut ini.

Tabel 1. Manifestasi Data Pergeseran Konteks Siber Pragmatik

\begin{tabular}{|c|c|c|}
\hline $\begin{array}{c}\text { Kode } \\
\text { Data }\end{array}$ & $\begin{array}{c}\text { Manifestasi } \\
\text { Data Siber } \\
\text { Pragmatik dan } \\
\text { Konteksnya }\end{array}$ & $\begin{array}{c}\text { Manifestasi } \\
\text { Pergeseran } \\
\text { Elemen } \\
\text { Konteks } \\
\end{array}$ \\
\hline & $\begin{array}{l}\text { Judul ini juga } \\
\text { bikin orang } \\
\text { salah persepsi } \\
\text { sama spt yg }\end{array}$ & $\begin{array}{l}\text { Konteks } \\
\text { Eksternal } \\
\text { Virtual: (1) } \\
\text { Penutur, } \\
\text { mitra tutur, }\end{array}$ \\
\hline
\end{tabular}

\begin{tabular}{|c|c|c|}
\hline DMPS1 & $\begin{array}{l}\text { dimuat dalam } \\
\text { kompas tv --- } \\
\text { apakah judul } \\
\text { harus spt itu? cc } \\
\text { @dewanpers } \\
\text { https://t.co/Ev } \\
\text { xAFxbsMj } \\
\text { Konteks: Ganjar } \\
\text { Pranowo } \\
\text { mengutip } \\
\text { sebuah laman } \\
\text { web }\end{array}$ & $\begin{array}{l}\text { dan pelibat } \\
\text { tutur lain; (2) } \\
\text { setting } \\
\text { suasana, } \\
\text { waktu, dan } \\
\text { tempat; (3) } \\
\text { maksud dan } \\
\text { tujuan; (4) } \\
\text { saluran dan } \\
\text { peranti } \\
\text { tuturan; (5) } \\
\text { genre dan } \\
\text { laras tuturan. }\end{array}$ \\
\hline $\begin{array}{l}\text { DMPS } \\
2\end{array}$ & $\begin{array}{l}\text { Sri Mulyani } \\
\text { memberikan } \\
\text { diskon tiket } \\
\text { penerbangan } \\
\text { 50\% lewat } \\
\text { insentif } \\
\text { pariwisata } \\
\text { akibat } \\
\text { mengatasi } \\
\text { dampak } \\
\text { penyebaran } \\
\text { corona } \\
\text { Konteks: Sri } \\
\text { Mulyani } \\
\text { mengingatkan } \\
\text { perusahaan } \\
\text { maskapai agar } \\
\text { memberikan } \\
\text { diskon kepada } \\
\text { wisatawan } \\
\text { mancanegara } \\
\text { bukan } \\
\text { menggunakan } \\
\text { insentif yang } \\
\text { diberikan oleh } \\
\text { pemerintah. } \\
\text { Berita ini } \\
\text { ditemukan di } \\
\text { Twitter } 17 \\
\text { Febrruari } 2020 \\
\text { pk } 21.32 .\end{array}$ & $\begin{array}{l}\text { Konteks } \\
\text { Eksternal } \\
\text { Virtual: (1) } \\
\text { Penutur, } \\
\text { mitra tutur, } \\
\text { dan pelibat } \\
\text { tutur lain; (2) } \\
\text { setting } \\
\text { suasana, } \\
\text { waktu, dan } \\
\text { tempat; (3) } \\
\text { maksud dan } \\
\text { tujuan; (4) } \\
\text { saluran dan } \\
\text { peranti } \\
\text { tuturan; (5) } \\
\text { genre dan } \\
\text { laras tuturan. }\end{array}$ \\
\hline
\end{tabular}




\begin{tabular}{|c|c|c|}
\hline DMPS3 & $\begin{array}{l}\text { BBC Indonesia } \\
\text { melakukan } \\
\text { wawancara } \\
\text { eksklusif } \\
\text { dengan } \\
\text { Presiden Joko } \\
\text { Widodo } \\
\text { Konteks: } \\
\text { Wawancara } \\
\text { oleh Presiden } \\
\text { Jokowi soal } \\
\text { kritikan } \\
\text { terhadap } \\
\text { dirinya tentang } \\
\text { penegakan } \\
\text { HAM, soal } \\
\text { korupsi, } \\
\text { lingkungan, } \\
\text { dinasti politik, } \\
\text { dan intolaransi } \\
\text { akhir Januari } \\
\text { lalu. Berita ini } \\
\text { ditemukan di } \\
\text { Twitter } 13 \\
\text { Februari } 2020 \\
\text { pk } 12.06 .\end{array}$ & $\begin{array}{l} \\
\text { Konteks } \\
\text { Eksternal } \\
\text { Virtual: (1) } \\
\text { Penutur, } \\
\text { mitra tutur, } \\
\text { dan pelibat } \\
\text { tutur lain; (2) } \\
\text { setting } \\
\text { suasana, } \\
\text { waktu, dan } \\
\text { tempat; (3) } \\
\text { maksud dan } \\
\text { tujuan; (4) } \\
\text { saluran dan } \\
\text { peranti } \\
\text { tuturan; (5) } \\
\text { genre dan } \\
\text { laras tuturan. }\end{array}$ \\
\hline & $\begin{array}{l}\text { Neraca dagang } \\
\text { tekor lagi, } \\
\text { Mentri } \\
\text { Perdagangan } \\
\text { salahkan corona } \\
\text { Konteks: } \\
\text { Menteri } \\
\text { Perdagangan, } \\
\text { Agus } \\
\text { Suparmanto } \\
\text { berkomentar } \\
\text { bahwa neraca } \\
\text { dagang di } \\
\text { Bulan Januari } \\
2020 \text { defisit } \\
\text { secara year on } \\
\text { year }\end{array}$ & $\begin{array}{l}\text { Konteks } \\
\text { Eksternal } \\
\text { Virtual: (1) } \\
\text { Penutur, } \\
\text { mitra tutur, } \\
\text { dan pelibat } \\
\text { tutur lain; (2) } \\
\text { setting }\end{array}$ \\
\hline
\end{tabular}

\begin{tabular}{|c|c|c|}
\hline DMPS4 & $\begin{array}{l}\text { dibandingkan } \\
\text { dengan Januari } \\
2019 . \\
\text { Perlambatan } \\
\text { ekpor ini } \\
\text { dikarenakan } \\
\text { China sebagai } \\
\text { Negara pertama } \\
\text { yang terjangkit } \\
\text { virus corona } \\
\text { memiliki } \\
\text { kontribusi besar } \\
\text { pada } \\
\text { perekonomian } \\
\text { Indonesia. } \\
\text { Berita ini } \\
\text { ditemukan di } \\
\text { Twitter } 17 \\
\text { Februari } 2020 \\
\text { pk } 21.46 .\end{array}$ & $\begin{array}{l}\text { suasana, } \\
\text { waktu, dan } \\
\text { tempat; (3) } \\
\text { maksud dan } \\
\text { tujuan; (4) } \\
\text { saluran dan } \\
\text { peranti } \\
\text { tuturan; (5) } \\
\text { genre dan } \\
\text { laras tuturan. }\end{array}$ \\
\hline $\begin{array}{l}\text { DMPS } \\
5\end{array}$ & $\begin{array}{l}\text { Korea Selatan } \\
\text { menunda } \\
\text { pemberian } \\
\text { bebas visa } \\
\text { sementara } \\
\text { waktu, dalam } \\
\text { situasi } \\
\text { pandemic } \\
\text { corona } \\
\\
\text { Konteks: } \\
\text { Pemerintah } \\
\text { Korea Selatan } \\
\text { mengumumkan } \\
\text { akan menunda } \\
\text { program bebas } \\
\text { VISA untuk } \\
\text { berbagai } \\
\text { negara, yang } \\
\text { melarang } \\
\text { masuk warga } \\
\text { Negeri } \\
\text { Gingseng } \\
\text { sebagai upaya } \\
\text { pencegahan } \\
\text { mengekang }\end{array}$ & $\begin{array}{l}\text { Konteks } \\
\text { Eksternal } \\
\text { Virtual: (1) } \\
\text { Penutur, } \\
\text { mitra tutur, } \\
\text { dan pelibat } \\
\text { tutur lain; (2) } \\
\text { setting } \\
\text { suasana, } \\
\text { waktu, dan } \\
\text { tempat; (3) } \\
\text { maksud dan } \\
\text { tujuan; (4) } \\
\text { saluran dan } \\
\text { peranti } \\
\text { tuturan; (5) } \\
\text { genre dan } \\
\text { laras tuturan. }\end{array}$ \\
\hline
\end{tabular}




\begin{tabular}{|c|c|c|}
\hline & $\begin{array}{l}\text { peningkatan } \\
\text { kasus COVID- } \\
19 \text { dari luar } \\
\text { negeri. Berita } \\
\text { ini ditemukan } \\
\text { di Twitter, } 9 \\
\text { April } 2020 \text { pk. } \\
12.00\end{array}$ & \\
\hline DMPS6 & $\begin{array}{l}\text { Izin diskotek } \\
\text { Black Owl } \\
\text { dicabut, Ketua } \\
\text { DPRD minta } \\
\text { Pemprov DKI } \\
\text { tak asal tutup } \\
\text { Konteks: } \\
\text { Pemprov DKI, } \\
\text { Prasetio menilai } \\
\text { bahwa } \\
\text { penutupan } \\
\text { diskotek dapat } \\
\text { dilakukan } \\
\text { apabila ada } \\
\text { keterlibatan } \\
\text { pihak } \\
\text { manajemen } \\
\text { terkait } \\
\text { penyalahgunaa } \\
\text { n narkotika. } \\
\text { Seharusnya ada } \\
\text { peringatan } \\
\text { terlebih dahulu } \\
\text { kepada pihak } \\
\text { diskotek. Berita } \\
\text { ini ditemukan } \\
\text { di Twitter, } 17 \\
\text { Februari } 2020 \\
\text { pk.21.52. }\end{array}$ & $\begin{array}{l} \\
\text { Konteks } \\
\text { Eksternal } \\
\text { Virtual: (1) } \\
\text { Penutur, } \\
\text { mitra tutur, } \\
\text { dan pelibat } \\
\text { tutur lain; (2) } \\
\text { setting } \\
\text { suasana, } \\
\text { waktu, dan } \\
\text { tempat; (3) } \\
\text { maksud dan } \\
\text { tujuan; (4) } \\
\text { saluran dan } \\
\text { peranti } \\
\text { tuturan; (5) } \\
\text { genre dan } \\
\text { laras tuturan. }\end{array}$ \\
\hline & $\begin{array}{l}\text { Siswi SMP } \\
\text { Purwerjo } \\
\text { dibully, Ganjar: } \\
\text { saya telepon } \\
\text { kepala } \\
\text { sekolahnya, } \\
\text { besok disidik } \\
\text { ambil tindakan }\end{array}$ & $\begin{array}{l}\text { Konteks } \\
\text { Eksternal } \\
\text { Virtual: (1) } \\
\text { Penutur, } \\
\text { mitra tutur, } \\
\text { dan pelibat } \\
\text { tutur lain; (2) }\end{array}$ \\
\hline
\end{tabular}

\begin{tabular}{|c|c|c|}
\hline DMPS7 & $\begin{array}{l}\text { Konteks: Ganjar } \\
\text { Pranowo } \\
\text { mengambil } \\
\text { tindakan yang } \\
\text { tegas terhadap } \\
\text { siswi yang } \\
\text { dibully di SMP } \\
\text { Purworejo. } \\
\text { Berita ini } \\
\text { ditemukan di } \\
\text { Twitter } 12 \\
\text { Februari } 2020 \\
\text { pk } 23.26 .\end{array}$ & $\begin{array}{l}\text { setting } \\
\text { suasana, } \\
\text { waktu, dan } \\
\text { tempat; (3) } \\
\text { maksud dan } \\
\text { tujuan; (4) } \\
\text { saluran dan } \\
\text { peranti } \\
\text { tuturan; (5) } \\
\text { genre dan } \\
\text { laras tuturan. }\end{array}$ \\
\hline \multirow[t]{2}{*}{$\begin{array}{l}\text { DMPS } \\
8\end{array}$} & $\begin{array}{l}\text { Pemerkosaan } \\
\text { dan diamnya } \\
\text { korban } \\
\text { Konteks: dr. } \\
\text { Jiemi Ardian } \\
\text { menulis di akun } \\
\text { twitternya } \\
\text { tentang } \\
\text { pemerkosaan } \\
\text { dan diamnya } \\
\text { korban. } \\
\text { Pemberian } \\
\text { dukungan } \\
\text { kepada korban } \\
\text { diperlukan } \\
\text { untuk } \\
\text { membantu } \\
\text { korban } \\
\text { bersuara dalam } \\
\text { pelaporan. } \\
\text { Jangan } \\
\text { menghakimi } \\
\text { korban. Berita } \\
\text { ini ditemukan } \\
\text { di Twitter } 17 \\
\text { Februari } 2020 \\
\text { pk. 19.15. }\end{array}$ & $\begin{array}{l}\text { Konteks } \\
\text { Eksternal } \\
\text { Virtual: (1) } \\
\text { Penutur, } \\
\text { mitra tutur, } \\
\text { dan pelibat } \\
\text { tutur lain; (2) } \\
\text { setting } \\
\text { suasana, } \\
\text { waktu, dan } \\
\text { tempat; (3) } \\
\text { maksud dan } \\
\text { tujuan; (4) } \\
\text { saluran dan } \\
\text { peranti } \\
\text { tuturan; (5) } \\
\text { genre dan } \\
\text { laras tuturan. }\end{array}$ \\
\hline & $\begin{array}{l}\text { Kebakaran } \\
\text { melanda } \\
\text { permukiman }\end{array}$ & \\
\hline
\end{tabular}




\begin{tabular}{|c|c|c|}
\hline DMPS9 & $\begin{array}{l}\text { Warga di Toraja } \\
\text { Utara, Sulawesi } \\
\text { Selatan. } \\
\text { Konteks: } \\
\text { Peristiwa } \\
\text { kebakaran di } \\
\text { Dusun Saleka } \\
\text { ini dikarenakan } \\
\text { letusan dari } \\
\text { atas lantai dua } \\
\text { rumah korban. } \\
\text { Kerugian } \\
\text { material milik } \\
\text { korban hingga } \\
\text { saat ini belum } \\
\text { dapat ditafsir. } \\
\text { Berita ini } \\
\text { ditemukan di } \\
\text { Twitter } 17 \\
\text { Februari } 2020 \\
\text { pk } 22.59 .\end{array}$ & $\begin{array}{l}\text { Konteks } \\
\text { Eksternal } \\
\text { Virtual: (1) } \\
\text { Penutur, } \\
\text { mitra tutur, } \\
\text { dan pelibat } \\
\text { tutur lain; (2) } \\
\text { setting } \\
\text { suasana, } \\
\text { waktu, dan } \\
\text { tempat; (3) } \\
\text { maksud dan } \\
\text { tujuan; (4) } \\
\text { saluran dan } \\
\text { peranti } \\
\text { tuturan; (5) } \\
\text { genre dan } \\
\text { laras tuturan. }\end{array}$ \\
\hline $\begin{array}{l}\text { DMPS1 } \\
\text { p }\end{array}$ & $\begin{array}{l}\text { Badai PHK } \\
\text { (Pemutusan } \\
\text { Hubungan } \\
\text { Kerja) melanda } \\
\text { Indonesia } \\
\text { dalam kurun } \\
\text { satu tahun } \\
\text { terakhir ini } \\
\text { Konteks : } \\
\text { Peneliti INDEF, } \\
\text { Fadhil Hasan } \\
\text { mengemukakan } \\
\text { harus } \\
\text { mendorong } \\
\text { investasi yang } \\
\text { berbasis } \\
\text { industry } \\
\text { manufaktur } \\
\text { yang } \\
\text { menciptakan } \\
\text { lapangan kerja. } \\
\text { Berita ini } \\
\text { ditemukan di }\end{array}$ & $\begin{array}{l}\text { Konteks } \\
\text { Eksternal } \\
\text { Virtual: (1) } \\
\text { Penutur, } \\
\text { mitra tutur, } \\
\text { dan pelibat } \\
\text { tutur lain; (2) } \\
\text { setting } \\
\text { suasana, } \\
\text { waktu, dan } \\
\text { tempat; (3) } \\
\text { maksud dan } \\
\text { tujuan; (4) } \\
\text { saluran dan } \\
\text { peranti } \\
\text { tuturan; (5) } \\
\text { genre dan } \\
\text { laras tuturan. }\end{array}$ \\
\hline
\end{tabular}

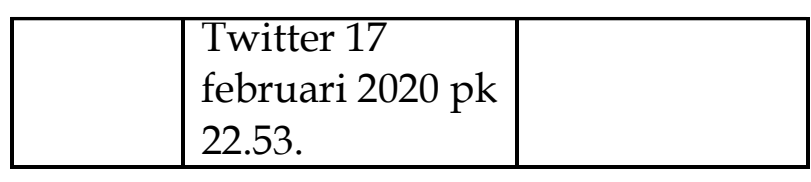

\section{Pembahasan}

Konteks dalam pragmatik siber tidak sepenuhnya sama dengan konteks pragmatik dalam pragmatik umum, pragmatik sistemik, ataupun pragmatik berbasis kultur-spesifik (Rahardi, 2016). Perbedaan itu terutama sekali tampak pada fakta kehadiran komunitas virtual. Kehadiran komunitas virtual itu mengubah atau menggeser kehadiran konteks konvensional dalam hal-hal berikut ini: (1) penutur, mitra tutur, dan pelibat tutur lain; (2) setting suasana, waktu, dan tempat; (3) maksud dan tujuan; (4) saluran dan peranti tuturan; (5) genre dan laras tuturan.

Dalam DMPS1 kehadiran konteks virtual itu ternyata menggeser persepsi konteks pragmatik yang menyangkut siapa hakikat penutur mitra tutur, dan pelibat tutur lain. Dalam pertuturan yang bersemuka, aspek-aspek seperti latar belakang jenis kelamin, usia, etnis, dan semacamnya sangat dipertimbangkan (Rahardi, 2018b). Akan tetapi dalam komunitas virtual seperti yang terdapat pada pragmatik siber, dimensi-dimensi itu seolah-olah lenyap menjadi tidak begitu penting lagi.

Dalam pertuturan yang tidak bersemuka, yang penting adalah imajinasi atau gambaran ilusif siapa sesungguhnya penutur, mitra tutur, dan para pelibat tutur yang lain. Dalam tuturan yang berbunyi, "Judul ini juga bikin orang salah persepsi sama spt yg dimuat dalam kompas tv apakah judul harus spt itu?", yang disampaikan seorang pejabat daerah ketika mengomentari judul berita yang menyangkut dirinya, tidak sama sekali tampak elemenelemen konteks tuturan yang mencakup penutur, mitra tutur, dan pelibat tutur yang lain (Gumperz, 2008). Tuturan tersebut 
seolah-olah dilepaskan dengan sama sekali tidak mengindahkan ketiga hal tersebut.

Jadi, jelas bahwa dalam konteks eksternal virtual pada tuturan dalam perspektif siber, aspek-aspek yang terdapat pada ketiga elemen itu dimanifestasikan secara berbeda. Orang tidak perlu bersantunsantun ria dengan sikap dan perilakunya seperti ketika orang bertutur secara bersemuka. Pertimbangan setting suasana, waktu, dan tempat juga berbeda dan bergeser antara pragmatik konvensional dan pragmatik dalam perspektif siber (Locher, 2013b). Orang dapat mengatakan bahwa dalam perspektif siber, setting yang mencakup ketiganya bersifat tidak berbatas alias borderless.

Berbeda sekali dengan tuturan dalam pragmatik konvensional yang selalu terikat dengan konsep 'empan-papan' alias tahu waktu dan tempat. Di dalam konteks eksternal virtual, pemahaman tentang setting suasana, waktu, dan tempat itu bergeser (Attardo, 2003). Dalam waktu kapan pun, dan dalam tempat di mana pun, seolah-olah tuturan apa pun juga dapat dilontarkan, dapat dicuitkan melalui media massa sosial seperti halnya Twitter. Hal lain yang juga perlu dicatat dalam mencermati maksud sebuah tuturan adalah bahwa komponen saluran dan peranti penyalur tuturan itu berbeda.

Perkembangan teknologi yang telah terjadi seolah-olah telah memaksa setiap orang untuk tidak lagi menggunakan peranti konvensional seperti amplifier atau pengeras suara untuk yang bertalian dengan suara, atau mungkin melalui surat formal untuk yang bersifat tertulis. Akan tetapi, peranti tuturan untuk pragmatik berperspektif siber itu demikian sederhana (Orsini-Jones et al., 2019).

Hanya dengan berbekalkan telepon pintar (smartphone) dengan segala peranti layanan yang ditawarkan di dalamnya secara cerdas, seolah-olah orang sudah dapat berbuat apa pun. Demikian pula ynag terjadi pada genre atau laras tuturannya, orang benar-benar dibebaskan dari keterikatan-keterikatan wacana dan laras seperti orang harus mempertimbangkan apakah laras tuturan ini formal, tidak formal, atau semacamnya. Pragmatik siber memberikan wadah pada semua kemerdekaan itu sehingga menafsirkan maksud dalam perspektif pragmatik siber menjadi tidak segampang menafsirkan maksud dalam pragmatik konvensiona (Nerlich, 2006).

Keambiguan dapat lebih sering dan lebih banyak terjadi karena batas-batas tidak semakin jelas melainkan justru semakin kabur (Briggs \& Bauman, 1992). Ujaran kebencian seakan-akan semakin bebas berkelana di dalam media sosial sebagai dampak dari kekaburan parameterparameter dalam komunitas virtual. Peneliti hendak menegaskan bahwa sesungguhnya hal ini merupakan akibat dari pergeseran konteks eksternal virtual yang terjadi pada pragmatik siber.

Selanjutnya, di dalam DMPS5 dengan data tuturan yang berbunyi, "Korea Selatan menunda pemberian bebas visa sementara waktu dalam situasi pandemi corona." Intepretasi serupa terjadi pula pada data ini. Tuturan yang berupa berita tersebut disampaikan tanpa memperhatikan identitas kelima komponen konteks seperti yang disampaikan di depan. Aspek yang pertama yang berkaitan dengan penutur, mitra tutur, dan pelibat tutur lain sama sekali tidak menjadi bagian dari apa yang harus diperhatikan dalam konteks pragmatik siber ini (Andrea \& Ágnes, 2019). Sementara itu, dalam pragmatik konvensional, pertimbangan akah kajatian penutur, mitra tutur, dan pelibat tutur lain menjadi salah satu penentu utama dalam pemberian maksud tuturan.

Dalam konteks tuturan yang disampaikan berkaitan dengan Korea Selatan itu, 
terbukti ketiganya tidak dipandang perlu untuk dipertimbangkan. Berita keluar dengan begitu saja seolah-olah lepas dan terbang secara liar. Substansi berita tersebut akan diterima sebagai pesan apa dipersilakan secara bebas. Dalam konteks setting suasana, waktu dan tempat terdapat satu aspek suasana yang sangat jelas disampaikan dalam pertututan itu, yakni suasana darurat berkaitan dengan pandemi Corona (Rahardi, 2020).

Konteks waktu juga dapat dicermati, yakni bawa berita terkait pemberian visa yang ditunda oleh Korea Selatan itu terjadi dalam waktu yang terbatas ini, yakni waktu seputar pandemi virus Corona. Dengan demikian dapat dipertegas bahwa konteks setting suasana, waktu, dan tempat, dapat disampaikan dengan jelas dengan konteks eksternal virtual dalam pragmatik siber. Aspek saluran dan peranti penyampaian tuturan juga sangat jelas berbeda antara konteks dalam pragmatik siber dan konteks dalam pragmatik konvensional.

Berita dan pesan tidak lagi disampaikan secara konvensional, tetapi disampaikan melalui layanan-layanan media sosial seperti halnya Twitter. Kalau saluran dalam konteks pragmatik konvensional dapat diatur oleh penuturnya, saluran dalam media sosial cenderung bebas dan berpotensi menjadi liar karena kemudahan-kemudahan yang ditawarkannya.

Dengan tanpa pertimbangan yang matang dan mendalam, kadang kala orang cepat-cepat memencet tombol dalam telepon pintar itu sehingga dalam sekejap saja pesan dan berita itu sudah akan menyebar ke seluruh dunia. Jangkauan saluran yang semula hanya sangat terbatas dan bersifat lokal sesuai dengan sifat dan karakteristik dari peranti salurannya, tetapi di dalam pragmatik siber ini, keterbatasanketerbatasan itu tidak lagi muncul (Rahardi, 2019b).
Berita yang baik dan buruk, pesan yang santun ataupun tidak santun, ujaran kebencian ataupun ujaran bijaksana, semuanya dapat sekejap menjangkau dunia dengan hanya sekali memencet tombol telepon pintar. Akan halnya dengan genre atau laras tuturan, substansi pesan tentang pemberian visa oleh Korea Selatan itu pun tidak diketahui kejelasan identitasnya, apakah larasnya keras, ataukah larasnya santun dan lembut, ataukah larasnya seperti apa, tidak teridentifikasi secara jelas dalam pragmatik siber ini.

Dalam DMPS10, tuturan yang berbunyi, “Badai PHK (Pemutusan Hubungan Kerja) melanda Indonesia dalam kurun satu tahun terakhir ini." dengan konteks tuturan berikut: "Peneliti INDEF, Fadhil Hasan mengemukakan harus mendorong investasi yang berbasis industri manufaktur yang menciptakan lapangan kerja. Berita ini ditemukan di Twitter 17 Februari 2020 pk 22.53.", menyiratkan pergeseran hakikat konteks dalam perspektif pragmatik siber tersebut sebagai berikut.

Elemen konteks pertama, yakni penuturmitra tutur-pelibat tutur lain, juga tidak menjadi perhatian utama bagi penyampai pesannya. Siapa berbicara apa, siapa menangkap maksud tuturan apa, dan sebatas apa pelibat tutur lain dapat terlibat di dalam penyampaian dan pemaknaan tuturan tersebut, tidak begitu diperhatikan dalam pertuturan ini. Jadi, memang sangat berbeda dengan pertuturan yang diintepretasi secara pragamatik konvensional dengan pertuturan yang diintepretasi secara siber.

Identitas komponan konteks yang kedua, yakni setting suasana-waktu-tempat juga tidak menjadi perhatian pokok dalam pertuturan yang diintepretasi dalam perspektif pragmatik siber (Rahardi, 2015). Suasana pertuturan cukup jelas diidentifikasi dalam pertuturan ini, yakni pemutusan hubungan kerja yang terjadi dalam 
suasana pandami Corona. Setting waktunya pun jelas, yakni dalam kurun waktu satu tahun. Akan tetapi, dari dimensi setting tempat kejelasan batas-batas itu menjadi tidak ada lagi. Jadi, memang benar-benar tidak berbatas teritorial (borderless). Pergeseran dalam penafsiran konteks demikian ini penting untuk dipahami agar pemaknaan tuturan menjadi tepat.

Pragmatik siber juga sekaligus mengajarkan kepada kita bahwa menafsirkan maksud tuturan tidak dapat selamanya berlaku konvensional karena konteks tuturan sesungguhnya telah bergeser menuju konteks eksternal virtual. Dengan demikian, pragmatik dipaksa berkembang dan bergeser, bukan lagi cukup dengan pragmatik umum, pragmatik sistemik, dan pragmatik kultur spesifik, tetapi sekarang ini sudah bergeser menjadi pragmatik siber (Locher, 2013a); (Orsini-Jones et al., 2019).

\section{PENUTUP}

Sebagai simpulan, perlu dinyatakan kembali bahwa ditemukan wujud-wujud pergeseran pada lima elemen konteks dalam pragmatik berperspektif siber. Kelima wujud pergeseran tersebut disampaikan sebagai berikut: (1) penutur, mitra tutur, dan pelibat tutur lain; (2) setting suasana, waktu, dan tempat; (3) maksud dan tujuan; (4) saluran dan peranti tuturan; (5) genre dan laras tuturan.

Dalam konteks eksternal virtual, hakikat dari kelima elemen konteks tersebut tidak sama dengan yang terjadi pada konteks eksternal konvensional karena dampak dari perkembangan digital. Pergeseran hakikat konteks menuju konteks eksternal virtual ini sangat penting untuk dipahami dalam menelaah maksud tuturan karena kalau yang digunakan selalu konteks eksternal konvensional, dan tidak mengakomodasi konteks eksternal virtual, yang banyak terjadi adalah kesalahpahaman. Ujaran yang sesungguhnya biasa saja maksudnya mudah dipandang sebagai ujaran yang tendensius, ujaran yang mengandung kebencian, dan seterusnya.

Di sisi yang lain, penutur juga harus lebih berhati-hati dalam bertutur melalui media sosial karena sekali orang tersebut berbuat kekeliruan dalam memerantikan maksud berbahasanya, dalam sekejap kesalahan itu akan sampai di seluruh penjuru dunia. Setiap tangan yang menggenggam gawai atau gadget pintar akan langsung dapat mengetahuinya dan itu artinya stigma-stigma tertentu akan mudah terpatri kepada seseorang yang tidak cermat memerantikan bahasanya dalam berkomunikasi.

\section{DAFTAR PUSTAKA}

Allan, K., \& Jaszczolt, K. 2012. The Cambridge handbook of pragmatics. Cambridge University Press. https://doi.org/10.1017/ CBO9781139029377

Andrea, B., \& Ágnes, V. 2019. Politeness and insult in computer games - from a pragmatic point of view. Magyar Nyelvor.

Attardo, S. 2003. Are socio-pragmatics and (Neo)-Gricean pragmatics incompatible? Journal of Pragmatics. https://doi.org/ 10.1016/s0378-2166(97)00051-9

Briggs, C. L., \& Bauman, R. 1992. Genre, Intertextuality, and Social Power. Journal of Linguistic Anthropology. https://doi.org/ 10.1525/jlin.1992.2.2.131

Giordano, C. 2016. Pragmatic Competence and Relevance. System. https://doi.org/10.1016/ j.system.2015.12.009

Gretsch, C. 2009. Pragmatics and integrational linguistics. Language and Communication. ht tps://doi.org/10.1016/ j.langcom.2009.02.010

Gumperz, J. J. 2008. Interactional Sociolinguistics: A Personal Perspective. In The Handbook of Discourse Analysis. 
https://doi.org/10.1002/ $9780470753460 . \operatorname{ch} 12$

Haider, I. 2019. Cyberpragmatics. In Global Perspectives on Language Assessment. https://doi.org/10.4324/9780429437922-11

Ishihara, N. 2010. Instructional pragmatics: Bridging teaching, research, and teacher education. Linguistics and Language Compass. https://doi.org/10.1111/j.1749818X.2010.00242.x

Kunjana Rahardi, R. 2020. Building critical awareness of corona virus-related news: Cyber-pragmatic study of COVID-19 hoaxes on social media. International Journal of Advanced Science and Technology.

Leech, G. 2007. Politeness: Is there an EastWest divide? Journal of Politeness Research. https://doi.org/10.1515/ PR.2007.009

Locher, M. A. 2013a. Cyberpragmatics: Internet-Mediated Communication in Context. Journal of Pragmatics. https:// doi.org/10.1016/j.pragma.2012.12.002

Locher, M. A. 2013b. Relational work and interpersonal pragmatics. Journal of Pragmatics. https://doi.org/10.1016/ j.pragma.2013.09.014

Mahsun, M. 2005. Metode Penelitian Bahasa. Jakarta: PT Raja Graûndo Persada. https:/ /doi.org/10.1200/JCO.2008.17.1991

Malinowski, B. 1925. Magic, science and religion. In Science, religion and reality. https://doi.org/10.2307/2104095

Nerlich, B. 2006. Pragmatics: History. In Encyclopedia of Language $\mathcal{E}$ Linguistics. https://doi.org/10.1016/B0-08-044854-2/ 00318-7

Orsini-Jones, M. E., Lloyd, E., Cribb, M., Lee, F., Bescond, G., Ennagadi, A., \& García, B. I. 2019. The Trouble With Cyberpragmatics. In Multicultural Instructional Design. https:/ /doi.org/10.4018/978-1-5225-9279-2.ch053
Rahardi, K. 2016. Personal and Communal Assumptions to Determine Pragmatic Meanings of Phatic Functions. Lingua Cultura, 10(2), 95.https://doi.org/10.21512/ lc.v10i2.897

Rahardi, R. 2017. Pragmatic Phenomena Constellation in Specific Culture Dimension LanguageStudy. International Journal of Humanity Studies. https://doi.org/ 10.24071/ijhs.2017.010109

Rahardi, R. K. 2015. Menemukan Hakikat Konteks Pragmatik. Prosiding Seminar PRASASTI. https://doi.org/10.20961/ PRAS.V0I0.63.G47

Rahardi, R. K. 2018a. Elemen dan Fungsi Konteks Sosial, Sosietal, dan Situasional dalam Menentukan Makna Pragmatik Kefatisan Berbahasa. In Prosiding Seminar Tahunan Linguistik Universitas Pendidikan Indonesia (SETALI 2018) (pp. 654-658). Bandung: Sekolah Pascasarjana Universitas Pendidikan Bandung.

Rahardi, R. K. 2018b. Elemen dan Fungsi Konteks Sosial, Sosietal, dan Situasional dalam Menentukan Makna Pragmatik Kefatisan Berbahasa. Dalam Prosiding Seminar Tahunan Linguistik Universitas Pendidikan Indonesia (SETALI 2018).

Rahardi, R. K. 2019a. Integrating social, societal, cultural, and situational contexts to develop pragmatics course learning materials: preliminary study (integrasi sosial, sosial, budaya, dan konteks situasional untuk mengembangkan materi pembelajaran pragmatik: studi awal). Gramatika STKIP PGRI Sumatera Barat. https://doi.org/ 10.22202/jg.2019.v5i2.3572

Rahardi, R. K. 2019b. Pragmatic Perspective on Phatic Functions and Language Dignity. International Journal of Engineering and Advanced Technology, 8(5C, May 2019), 261-268. https://doi.org/DOI: 10.35940/ijeat.E1039.0585C19 
Rahardi, R. K. 2020. Pragmatic meanings of javanese phatic marker 'sampun': culture-specific pragmatic perspective. RETORIKA: Jurnal Bahasa, Sastra, Dan Pengajarannya. https://doi.org/10.26858/ retorika.v13i1.11227

Sembiring, R. J. B., Pranowo, P., \& Rahardi, R. K. 2019. Pengembangan buku ajar konteks situasi dan sosial dalam pragmatik edukasionaL. Jurnal Pendidikan Bahasa Dan Sastra. https://doi.org/10.17509/ bs_jpbsp.v18i2.15512

Sudaryanto. 2016. Metode dan Aneka Teknik Analisis Bahasa (1st ed.). Yogyakarta: Sanata Dharma University Press.
Wijana, I. D. P. 2014. Bahasa, Kekuasaan, Dan Resistansinya: Studi Tentang NamaNama Badan Usaha Di Daerah Istimewa Yogyakarta. Jurnal Humaniora.

Yu, K. A. 2011. Culture-specific concepts of politeness: Indirectness and politeness in English, Hebrew, and Korean requests. Intercultural Pragmatics. https://doi.org/ 10.1515/IPRG.2011.018

Yus, F. 2012. Cyberpragmatics. In The Encyclopedia of Applied Linguistics. https:// doi.org/10.1002/9781405198431.wbeal0309. 